\title{
Methane Production of Fresh Sainfoin, with or without PEG, and Fresh Alfalfa at Different Stages of Maturity is Similar but the Fermentation End Products Vary
}

\author{
Pablo José Rufino-Moya ${ }^{D}$, Mireia Blanco, Juan Ramón Bertolín and Margalida Joy *(D) \\ Centro de Investigación y Tecnología Agroalimentaria de Aragón (CITA), Instituto Agroalimentario de \\ Aragón-IA2 (CITA-Universidad de Zaragoza), Avda, Montañana 930, 50059 Zaragoza, Spain; \\ pjrufino@cita-aragon.es (P.J.R.-M.); mblanco@aragon.es (M.B.); jrbertolin@cita-aragon.es (J.R.B.) \\ * Correspondence: mjoy@aragon.es; Tel.: +34-976-716-442
}

Received: 14 March 2019; Accepted: 18 April 2019; Published: 26 April 2019

Simple Summary: In the last years, there has been increasing interest in the use of forages containing condensed tannins (CT) in ruminant nutrition. Condensed tannins can reduce the methane emissions and the ruminal degradation of protein, improving the animal performances to different extents depending on the source and dose of CT. In vitro fermentation of sainfoin has not been studied in fresh forage. The effect of CT can be studied in comparison with a similar CT-free forage or using polyethylene glycol (PEG), which is a tannin-blocking agent. The maturity stage influences the chemical composition to a different degree depending on the legume species, and can affect the content and fractions of CT. The aims of this trial were to compare the fermentation parameters of sainfoin with or without PEG, to detect the differences due to $\mathrm{CT}$, at different maturity stages (vegetative, start-flowering, and end-flowering) and compare them with the fermentation parameters of alfalfa. The main results were that sainfoin had greater in vitro organic matter degradability (IVOMD) and lower ammonia and acetic:propionic ratio than alfalfa. Sainfoin CT had effect on ammonia and individual fatty acid proportions. In conclusion, fermentation end products were affected both by the chemical composition and CT contents.

\begin{abstract}
Alfalfa and sainfoin are high-quality forages with different condensed tannins (CT) content, which can be affected by the stage of maturity. To study the effects of CT on fermentation parameters, three substrates (alfalfa, sainfoin, and sainfoin+PEG) at three stages of maturity were in vitro incubated for $72 \mathrm{~h}$. Sainfoin had greater total polyphenol and CT contents than alfalfa. As maturity advanced, $\mathrm{CT}$ contents in sainfoin decreased $(p<0.05)$, except for the protein-bound CT fraction $(p>0.05)$. The total gas and methane production was affected neither by the substrate nor by the stage of maturity $(p>0.05)$. Overall, sainfoin and sainfoin+PEG had greater in vitro organic matter degradability (IVOMD) than alfalfa $(p<0.05)$. Alfalfa and sainfoin+PEG presented higher ammonia content than sainfoin $(p<0.001)$. Total volatile fatty acid (VFA) production was only affected by the stage of maturity $(p<0.05)$, and the individual VFA proportions were affected by the substrate and the stage of maturity $(p<0.001)$. In conclusion, alfalfa and sainfoin only differed in the IVOMD and the fermentation end products. Moreover, CT reduced ammonia production and the ratio methane: VFA, but the IVOMD was reduced only in the vegetative stage.
\end{abstract}

Keywords: polyethylene glycol; gas production; in vitro organic matter degradability; condensed tannins; ammonia; volatile fatty acid; in vitro assay 


\section{Introduction}

There is increasing interest in legume-based forage production systems because of their low reliance on fertilizer nitrogen, potential environmental benefits, and high protein content that contribute to low-input and sustainable livestock production systems [1]. Alfalfa (Medicago sativa L.) and sainfoin (Onobrychis viciifolia Scop.) are two pluriannual legumes widely grown in the Mediterranean area, presenting high forage productive capacity, high nutritional value, and restorative action for soil fertility [2]. However, alfalfa has a low content of polyphenols and is considered virtually free of condensed tannins (CTs), whereas sainfoin presents a high content of polyphenols and a medium to high content of CTs [3-5].

Alfalfa is usually fed as hay to ruminants mainly to avoid bloat, although continuous grazing is possible without bloat incidence both in sheep [6] and growing cattle [7]. Thus, the majority of studies that compared the ruminal fermentation of alfalfa and sainfoin have been performed using hays $[3,4,8]$. The differences between alfalfa and sainfoin have been ascribed to differences in the chemical compositions [4], but also to the presence of CTs [8]. To clarify whether the differences between alfalfa and sainfoin are only due to CTs, polyethylene glycol (PEG) must be added as a tannin-blocking agent [8]. To the best of our knowledge, the ruminal fermentation of both species was compared in fresh forages only by McMahon et al. [9] and Chung et al. [10]. Depending on their content, characteristics, and properties [11], CTs from sainfoin alter both the breakdown of protein in the rumen to ammonia and methane, gas and the production of total volatile fatty acids (VFAs) [3,4,12]. These, in turn, are associated with the variety, stage of maturity, and environmental factors $[5,13,14]$.

The objectives of this trial were to compare the in vitro fermentation of alfalfa and sainfoin at three stages of maturity and to clarify whether the differences between both legumes were due to the CTs of sainfoin using PEG.

\section{Materials and Methods}

\subsection{Experimental Design}

Three substrates (alfalfa, sainfoin, and sainfoin+PEG) at three stages of maturity (vegetative, start-flowering, and end-flowering) were used to evaluate the effect of sainfoin CTs on in vitro fermentation. Alfalfa was used as a tannin-free legume.

\subsection{Animal and Diets}

\subsubsection{Forages, Crop Management, and Harvest}

The experiment was performed at the CITA Research Institute at Zaragoza $\left(41^{\circ} 42^{\prime} \mathrm{N}, 0^{\circ} 49^{\prime} \mathrm{W}\right)$, altitude $216 \mathrm{~m}$ a.s.l., located in Ebro Valley, north-eastern Spain. The silt loam soil at the site had pH 8.1 and $1.81 \%$ organic matter and contained $16 \%$ clay, $53.5 \%$ silt, and $30.5 \%$ sand. Alfalfa and sainfoin were cultivated and managed as described by Lobón et al. [15]. Samples of forage were collected fortnightly from 14 April to 22 September 2015. The stage of maturity of the sainfoin and alfalfa was classified into vegetative, start-flowering, and end-flowering according to Borreani et al. [16] and Kalu and Fick [17], respectively. In each sampling, 10 samples per legume were obtained from $0.25 \mathrm{~m}^{2}$ areas randomly allocated in the plot. These samples were mixed homogenously, and a part of the sample was separated manually into stems, leaves, and flowers to study their respective percentages. Another part of the samples was dried at $60{ }^{\circ} \mathrm{C}$ for $48 \mathrm{~h}$ for chemical analyses, and the rest of the sample was freeze-dried in a Genesis Freeze Dryer 25 (Hucoa Erlöss, SA/Thermo Fisher Scientific, Madrid, Spain) for polyphenol and CT analyses and in vitro fermentation assays. Samples for the chemical analyses were ground and sieved through a 1-mm screen (Rotary Mill, ZM200 Retsch, Hann, Germany), and a part of the samples was ground and sieved through a $0.2-\mathrm{mm}$ screen for crude protein $(\mathrm{CP})$, polyphenol, and $\mathrm{CT}$ determination. All the samples were stored at $-20^{\circ} \mathrm{C}$ in total darkness. 
The number of samples of vegetative, start-flowering and end-flowering stages of each forage to study the in vitro fermentation were chosen in concordance with the representativeness of the plant development. The vegetative stage was the most frequent stage (55\%), followed by end-flowering $(27 \%)$ and start-flowering (18\%) stages. Three samples of the vegetative stage and two samples of the start- and end-flowering of each legume species were studied.

\subsubsection{Animals and Sampling of Ruminal Digesta}

The procedures used in the trial followed the Spanish guidelines for experimental animal protection (RD 53/2013) and were approved by the Institutional Animal Care and Use Committee of the Research Centre (Procedure number 2011-05). Rasa Aragonesa wethers ( $\mathrm{n}=4$; Live weight: $65 \pm 2.1 \mathrm{~kg}$ ) were used as donors of ruminal content. The management of the rumen-cannulated wethers and the sampling of the ruminal digesta was made as reported in Rufino-Moya et al. [18]. Briefly, wethers were fed a diet composed by alfalfa hay (70\%) and barley grain (30\%) at energy maintenance level. Before morning feeding, ruminal digesta from each wether was collected into a prewarmed insulated thermo, individually strained through four layers of cheesecloth and homogenized. Rumen fluid from the four wethers was mixed (pH: $6.76 \pm 0.099$ ), and a buffer solution was added in a proportion of 1:2 $(v / v)$ based on the protocol of Menke and Steingass [19]

\subsubsection{In Vitro Gas Production Technique and Sampling}

The production of gas was measured with the Ankom system (Ankom Technology Corporation, Fairport, NY, USA), which had $310 \mathrm{~mL}$ capacity bottles fitted with pressure and temperature sensors. The valve open time was one second, the threshold for gas release was 5 PSI and the bottles were not shaken. Five hundred mg of freeze-dried substrate (alfalfa, sainfoin, or sainfoin+PEG) were incubated with $60 \mathrm{~mL}$ of buffered solution:rumen fluid $(2: 1 \mathrm{v} / \mathrm{v})$ in a water bath $\left(\right.$ at $\left.39{ }^{\circ} \mathrm{C}\right)$ for $72 \mathrm{~h}$. To make the sainfoin+PEG samples, PEG-4000 (Merck, Darmstadt, Germany) was added to the buffered rumen fluid at a concentration of $2.3 \mathrm{~g} / \mathrm{L}$ [12]. Four runs were conducted on four separate days, and each sample was incubated in duplicate in each run. Gas production and corrected with the blanks (two bottles without substrate were included in each run).

After $72 \mathrm{~h}$ of incubation, the bottles were placed in ice to stop fermentation (5-10 min), and then tempered (at room temperature for 10-15 min). A sample of the gas produced was transferred (at atmospheric pressure) with a syringe attached to a manometer into a Vacutainerßtube to determine $\mathrm{CH}_{4}$ and conserved at $4{ }^{\circ} \mathrm{C}$ until analysis. At the end of gas sampling, the $\mathrm{pH}$ was measured immediately with a microPH 2002 (Crison Instruments S.A., Barcelona, Spain). The sampling to determine ammonia $\left(\mathrm{NH}_{3}-\mathrm{N}\right)$ content and VFA were carried out as reported in Rufino-Moya et al. [18]. Briefly, to determine the ammonia content, $2.5 \mathrm{~mL}$ of liquid was mixed with $2.5 \mathrm{~mL} \mathrm{HCl} \mathrm{0.1} \mathrm{N}$. For VFA determination, $0.5 \mathrm{~mL}$ of the liquid was added to $0.5 \mathrm{~mL}$ of deproteinizing solution and $1 \mathrm{~mL}$ of distilled water. Tubes with samples for determination of ammonia and VFAs were stored at $-20{ }^{\circ} \mathrm{C}$ until future analyses. The entire incubated sample was filtered through a preweighed bag (50 $\mu \mathrm{m} ;$ Ankom) to estimate the in vitro organic matter degradability (IVOMD). Briefly, the bags were sealed, washed, dried at $103{ }^{\circ} \mathrm{C}$ for $48 \mathrm{~h}$, and finally, placed in a muffle at $550^{\circ} \mathrm{C}$ to obtain the ashes. The organic matter of the bag content was obtained as DM-ashes, and the IVOMD was calculated.

\subsection{Analytical Methods}

\subsubsection{Chemical Composition}

All the analyses of the chemical composition were analyzed as reported in Rufino-Moya et al. [18] according to official methods. Briefly, AOAC methods were used to determine the contents of dry matter (index no. 934.01), ash (index no. 942.05), and CP (index no. 968.06) [20]. Neutral detergent fiber (NDFom), acid detergent fiber (ADFom), and lignin (sa) contents were determined according to the method described by Van Soest et al. [21] using the Ankom 200/220 fiber analyzer (Ankom Technology 
Corporation). The NDFom was assayed with a heat stable amylase. The lignin (sa) was analyzed in ADF residues by the solubilization of cellulose with sulfuric acid. All the values were corrected for ash-free content. The ether extract (EE) was determined following the approved procedure Am 5-04 [22] using an XT10 Ankom extractor (Ankom Technology Corporation). The nonstructural carbohydrates (NSC) were calculated as NSC $=1000-C P-E E-N D F-$ ash, according to Guglielmelli et al. [3].

The content of total polyphenol (TP) and the fractions of CT were determined as described in Rufino-Moya et al. [18]. Briefly, the TP were extracted using the method of Makkar [23] and were quantified following the method of Julkunen-Tiitto [24]. The extractable CT (ECT), protein-bound $\mathrm{CT}$ (PBCT), and fiber-bound CT (FBCT) were extracted and fractioned following the method of Terrill et al. [25] and quantified by the colorimetric HCl-butanol method described by Grabber et al. [26]. The standard used for the quantification was extracted and purified from sainfoin using the method

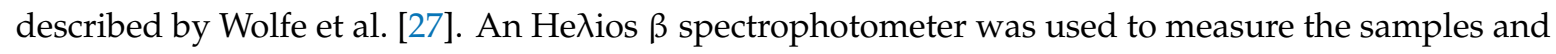
standard calibration at $550 \mathrm{~nm}$.

\subsubsection{Determination of Parameters of the In Vitro Gas Production Technique}

Gas production, recorded hourly for $72 \mathrm{~h}$, was used to estimate the parameters of the kinetics of fermentation adjusting the gas produced to the model described by France et al. [28]:

$$
P=A \times\left(1-e^{-c t}\right)
$$

where $P$ is the cumulative gas production $(\mathrm{mL})$ at time $t(\mathrm{~h}), A$ is the potential gas production $(\mathrm{mL})$, and $c$ is the rate of gas production $\left(\mathrm{h}^{-1}\right)$.

An HP-4890 (Agilent, St. Clara, CA, USA) gas chromatograph (GC) equipped with a flame ionization detector (FID) and a TG-BOND Q+ capillary column $(30 \mathrm{~m} \times 0.32 \mathrm{~mm}$ id $\times 10 \mu \mathrm{m}$ film thickness, Thermo Scientific, Waltham, MA, USA) was used to determine $\mathrm{CH}_{4}$. Helium was used as the carrier gas at a flow rate of $1 \mathrm{~mL} / \mathrm{min}$. The oven temperature was maintained at $100{ }^{\circ} \mathrm{C}$ (isothermal program). The splitless injection volume was $200 \mu \mathrm{L}$. Methane identification was based on the retention time compared with the standard. The methane concentration was calculated from the peak concentration:area ratio using the peak area generated from standard gas as the reference $\left(\mathrm{CH}_{4}\right.$; 99.995\% purity [C45], Carburos Metálicos, Barcelona, Spain).

The content of ammonia was measured in Epoch microplate Spectrophotometer (BioTek Instruments, Inc., Winooski, VT, USA) using a colorimetric method described by Chaney and Marbach [29].

A Bruker Scion 460 GC (Bruker, Billerica, MA, USA) equipped with CP-8400 autosampler, FID and a BR-SWax capillary column $(30 \mathrm{~m} \times 0.25 \mathrm{~mm}$ i.d. $\times 0.25 \mu \mathrm{m}$ film thickness, Bruker) was used to determine the concentration of acetic, propionic, iso-butyric, butyric, iso-valeric, and valeric acids. Helium was the carrier gas (flow rate of $1 \mathrm{~mL} / \mathrm{min}$ ). The oven temperature program was $100{ }^{\circ} \mathrm{C}$, followed by a $6{ }^{\circ} \mathrm{C} / \mathrm{min}$ increase to $160^{\circ} \mathrm{C}$. The injection volume was $1 \mu \mathrm{L}$ at a split ratio of 1:50. The individual VFAs were identified based on retention time comparisons with commercially available standards of acetic, propionic, iso-butyric, butyric, iso-valeric, valeric, and 4-methyl-valeric acids at $\geq 99 \%$ purity (Sigma-Aldrich, St. Louis, MO, USA).

\subsection{Statistical Analyses}

Data were analyzed using SAS v. 9.3 (SAS Inst. Inc., Cary, NC, USA). The fermentation kinetic parameters $(A$ and $c$ ) were estimated using a nonlinear regression model (NLIN procedure). The contents of secondary compounds were analyzed using the GLM procedure with the substrate, the stage of maturity and its interaction as fixed effects. Total gas and $\mathrm{CH}_{4}$ production, $A, c$, IVOMD and the fermentation end products were analyzed using mixed models considering the substrate, the stage of maturity and its interaction as fixed effects and the run as random effect. If the interaction was not significant, it was deleted from the model and the analysis was repeated. The least square means, their 
associated standard errors and the differences were obtained. Pearson correlation coefficients between variables were calculated using the CORR procedure. For the entire test, the effects were considered a significant probability at a value of $p<0.05$ or a trend at $p=0.05$.

\section{Results}

\subsection{Chemical Composition}

The chemical composition and the percentage of stems, leaves, and flowers of both legume species at the three stages of maturity are shown in Table 1. On average, alfalfa and sainfoin had similar ADFom (231 g/kg DM), CP (198 g/kg DM), EE (15 g/kg DM), and NSC (335 g/kg DM) contents. Alfalfa, however, had higher ash and NDFom contents and a lower lignin (sa) content than sainfoin. For both forages, NDFom and ADFom content increased as the stage of maturity progressed, whereas the $\mathrm{CP}$ content decreased. As the forage matured, the lignin (sa) content increased only in alfalfa whereas the contents of EE and NSC decreased only in sainfoin.

Table 1. Chemical composition and plant components of alfalfa and sainfoin at three stages of maturity.

\begin{tabular}{|c|c|c|c|c|c|c|}
\hline Item & \multicolumn{3}{|c|}{ Alfalfa } & \multicolumn{3}{|c|}{ Sainfoin } \\
\hline \multicolumn{7}{|l|}{ Chemical composition } \\
\hline Dry Matter (DM) (g/kg) & 249 & 261 & 333 & 241 & 262 & 224 \\
\hline Ash (g/kg DM) & 103 & 111 & 98 & 83 & 113 & 82 \\
\hline $\mathrm{CP}^{1}(\mathrm{~g} / \mathrm{kg} \mathrm{DM})$ & 227 & 207 & 166 & 204 & 201 & 181 \\
\hline Lignin (sa), (g/kg DM) & 45 & 53 & 66 & 78 & 76 & 76 \\
\hline Ether extract (g/kg DM) & 18 & 10 & 16 & 22 & 15 & 11 \\
\hline $\mathrm{NSC}^{4}(\mathrm{~g} / \mathrm{kg} \mathrm{DM})$ & 317 & 320 & 316 & 379 & 347 & 332 \\
\hline \multicolumn{7}{|l|}{ Plant components (\%) } \\
\hline Leaves & 59.3 & 53.7 & 42.7 & 66.3 & 56.0 & 38.5 \\
\hline
\end{tabular}

${ }^{1}$ crude protein; ${ }^{2}$ Neutral detergent fiber; ${ }^{3}$ acid detergent fiber; ${ }^{4}$ nonstructural carbohydrates.

Alfalfa and sainfoin had similar proportions of leaves (51.9 vs. 53.6\%). However, alfalfa had a greater proportion of stems (45.2 vs. $39.7 \%)$ and a lower proportion of flowers (2.8 vs. $6.7 \%)$ than sainfoin. Regarding the stage of maturity, the proportion of stems and flowers increased, whereas the proportion of leaves decreased as the stage of maturity advanced.

\subsection{Contents of Total Polyphenols and Condensed Tannins}

The content of total polyphenols and the total (TCT) and fractions of CT were affected by the interaction between the legume species and the stage of maturity $(p<0.05)$ (Figure 1$)$. Alfalfa presented steady contents of total polyphenols, TCTs, ECTs, PBCTs, and FBCTs, which were lower than those of sainfoin $(p<0.001)$ regardless of the stage of maturity. The contents of polyphenols, TCTs, ECTs, and FBCTs decreased as maturity advanced $(p<0.05)$. 

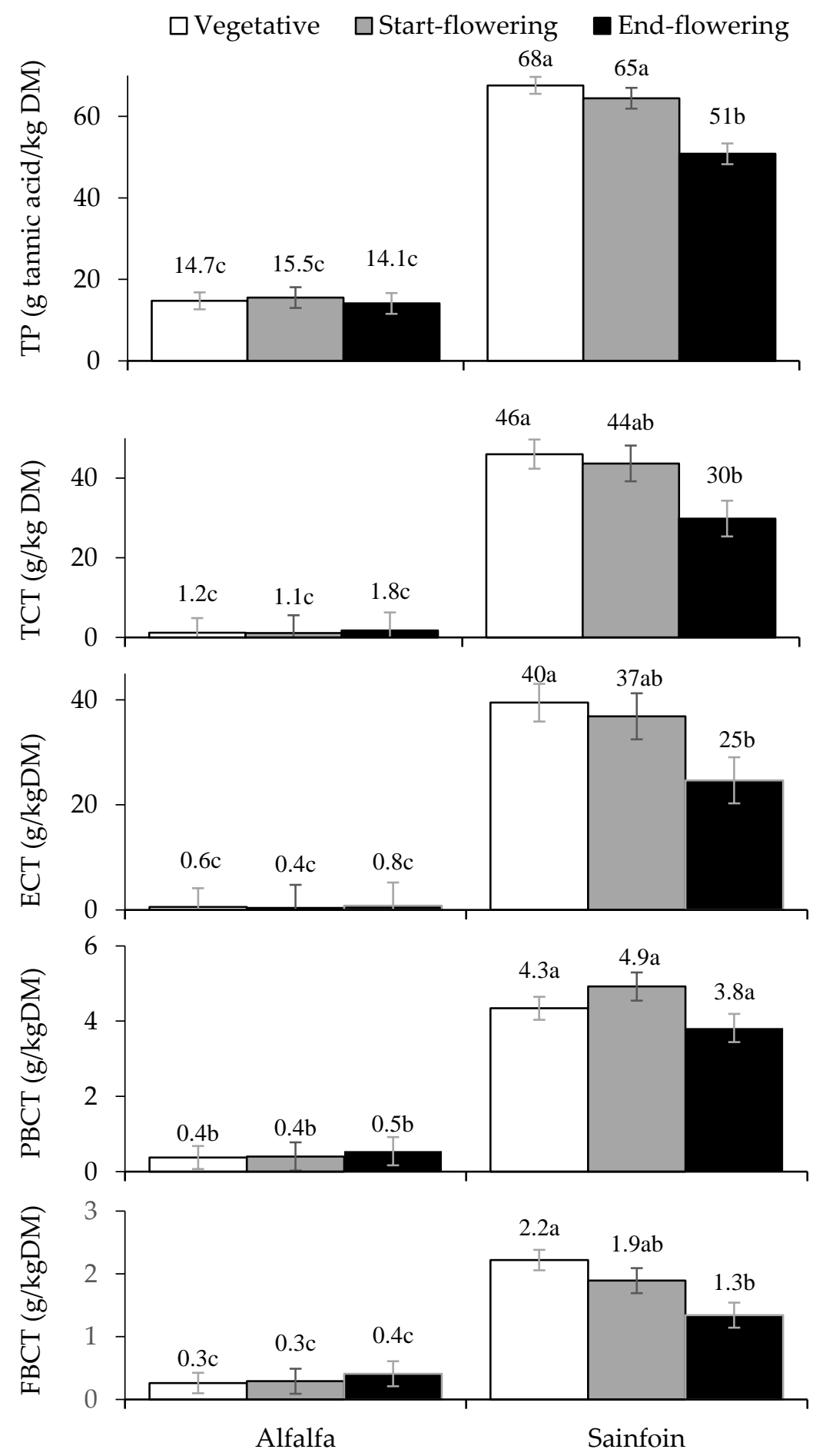

Figure 1. Effect of the species and the stage of maturity on the contents of total polyphenols (TP), total condensed tannins (TCT), extractable CT (ECT), protein-bound CT (PBCT), and fiber-bound (FBCT). Within a parameter, means with different letter differ at $p<0.05$. (Within each species: $\mathrm{n}=3$ for the vegetative stage, $n=2$ for the start-flowering, and $n=2$ for the end-flowering stages.)

\subsection{In Vitro Fermentation}

The $\mathrm{pH}$ was affected by the interaction between the substrate and the stage of maturity $(p<0.01$; Table 2). Alfalfa had greater $\mathrm{pH}$ than sainfoin and sainfoin $+\mathrm{PEG}(p<0.05)$. Sainfoin and sainfoin $+\mathrm{PEG}$ were affected similarly by the stage of maturity $(p<0.001)$, with the greatest $\mathrm{pH}$ value in the vegetative 
stage $(p<0.05)$ Total gas and $\mathrm{CH}_{4}$ production were affected neither by the substrate nor by the stage of maturity ( $p>0.05$; Table 2). However, the interaction between the substrate and the stage of maturity affected $A(p<0.001)$ and c $(\mathrm{p}=0.05)$. Alfalfa showed lower $A$ values at start-and end-flowering stages $(p<0.001)$ and greater $c$ in the vegetative and start-flowering stages $(p<0.05)$ than sainfoin and sainfoin+PEG $(p<0.05)$. Regarding the effect stage of maturity, sainfoin and sainfoin + PEG had the lowest $A$ values in the vegetative stage $(p<0.05)$. As the stage of maturity progressed, $c$ increased in sainfoin and sainfoin+PEG substrates $(p<0.05)$.

The IVOMD was also affected by the interaction between the substrate and the stage of maturity $(p<0.001$; Table 2). Alfalfa had lower IVOMD than both sainfoin substrates in the start-flowering and end-flowering stages $(p<0.05)$, whereas sainfoin+PEG had greater IVOMD than alfalfa and sainfoin in the vegetative stage $(p<0.05)$. In alfalfa, the IVOMD decreased as the stage of maturity advanced $(p<0.05)$. The sainfoin and sainfoin+PEG showed the greatest IVOMD in the start-flowering stage $(p<0.05)$. The IVOMD was correlated with $A(\mathrm{r}=0.60 ; P<0.01)$ and with the total VFA production $(\mathrm{r}=0.51 ; p<0.05)$.

The $\mathrm{NH}_{3}-\mathrm{N}$ content was only affected by the substrate $(p<0.001)$; sainfoin produced a lower $\mathrm{NH}_{3}-\mathrm{N}$ concentration than alfalfa and sainfoin+PEG (Table 2). In contrast, total VFA production was only affected by the stage of maturity $(p<0.05)$, the start-flowering stage presented greater VFA production than the rest of the stages $(105,99$, and $100 \mathrm{mmol} / \mathrm{L}$ for start-flowering, vegetative, and end-flowering, respectively). Regarding the individual VFAs, alfalfa had a lower acetic acid proportion and greater proportions of the rest of the individual VFAs than sainfoin $(p<0.001)$. When comparing both sainfoin substrates, sainfoin had a greater acetic acid proportion and lower proportions of the rest of the VFAs than sainfoin+PEG $(p<0.001)$. Sainfoin presented the greatest $C_{2}: C_{3}$ ratio, followed by sainfoin+PEG and alfalfa, which had the lowest ratio $(p<0.001)$. Regarding the effect of the stage of maturity, the vegetative stage had a lower proportion of acetic acid and greater proportions of propionic, iso-butyric, and iso-valeric acid than the rest of stages of maturity $(p<0.001)$. The vegetative stage had a lower $C_{2}: C_{3}$ ratio than the other stages $(p<0.001)$. The $\mathrm{CH}_{4}$ :VFA ratio was only affected by the substrate $(p=0.01)$; sainfoin+PEG presented a greater $\mathrm{CH}_{4}$ :VFA ratio than the other substrates $(p<0.05)$. 
Table 2. Effect of the substrate $(\mathrm{S})$ and the stage of maturity ${ }^{1}(\mathrm{SM})$ on gas and methane production $\left(\mathrm{CH}_{4}\right)$, potential gas production $(A)$, rate of gas production $(c)$, in vitro organic matter degradability (IVOMD), ammonia $\left(\mathrm{NH}_{3}-\mathrm{N}\right)$, and volatile fatty acids (VFAs).

\begin{tabular}{|c|c|c|c|c|c|c|c|c|c|c|c|c|c|}
\hline \multirow[b]{2}{*}{ Item } & \multicolumn{3}{|c|}{ Alfalfa } & \multicolumn{3}{|c|}{ Sainfoin } & \multicolumn{3}{|c|}{ Sainfoin+PEG } & \multirow[b]{2}{*}{ r.s.d. ${ }^{2}$} & \multicolumn{3}{|c|}{$p$-Values } \\
\hline & VEG & Start-F & End-F & VEG & Start-F & End-F & VEG & Start-F & End-F & & $\mathrm{S}$ & SM & SxSM \\
\hline $\mathrm{pH}$ & $6.42^{\mathrm{a}}$ & $6.44^{\mathrm{a}}$ & $6.41^{\mathrm{a}}$ & $6.35^{\mathrm{bx}}$ & 6.32 by & 6.33 by & $6.37^{b x}$ & $6.31 \mathrm{bz}$ & 6.34 by & 0.032 & $<0.001$ & 0.002 & 0.01 \\
\hline Gas production $\left(\mathrm{mL} / \mathrm{g} \mathrm{dOM}^{3}\right)$ & 179 & 184 & 188 & 183 & 163 & 181 & 180 & 199 & 173 & 26.5 & 0.43 & 0.97 & 0.12 \\
\hline$A(\mathrm{~mL})$ & $68^{x}$ & $67^{b x y}$ & $62 \mathrm{y}$ & $63^{y}$ & $74^{b x}$ & $70^{x}$ & $65^{y}$ & $78^{\text {ax }}$ & $67 \mathrm{y}$ & 5.7 & 0.01 & $<0.001$ & $<0.001$ \\
\hline$c\left(\mathrm{~h}^{-1}\right)$ & $0.2^{\mathrm{a}}$ & $0.22^{\mathrm{a}}$ & 0.19 & 0.14 by & $0.16^{\text {bxy }}$ & $0.19 \mathrm{y}$ & $0.15^{b x}$ & $0.15^{b x}$ & $0.19^{\mathrm{y}}$ & 0.037 & $<0.001$ & 0.02 & 0.05 \\
\hline $\mathrm{CH}_{4}$ production $\left(\mathrm{mL} / \mathrm{g} \mathrm{dOM}^{3}\right)$ & 37 & 38 & 39 & 37 & 33 & 38 & 37 & 39 & 36 & 5.0 & 0.29 & 0.73 & 0.17 \\
\hline $\mathrm{CH}_{4}: \operatorname{gas}(\mathrm{mL} / \mathrm{L})$ & 145 & 142 & 141 & $141^{x y}$ & $134^{\mathrm{y}}$ & $148^{\mathrm{x}}$ & 145 & 144 & 144 & 8.8 & 0.35 & 0.13 & 0.11 \\
\hline IVOMD $(\mathrm{g} / \mathrm{kg})$ & $851^{b x}$ & $837^{b x}$ & 770 by & 850 by & $926^{\text {ax }}$ & $856^{\text {ay }}$ & $868^{\text {ay }}$ & $936^{\text {ax }}$ & $864^{\text {ay }}$ & 16.9 & $<0.001$ & $<0.001$ & $<0.001$ \\
\hline $\mathrm{NH}_{3}-\mathrm{N}(\mathrm{mg} / \mathrm{L})$ & $240^{\mathrm{a}}$ & $247^{\mathrm{a}}$ & 210 & $206^{\mathrm{b}}$ & $184^{\mathrm{b}}$ & 201 & $242^{a}$ & $234^{a}$ & 215 & 31.7 & $<0.001$ & 0.06 & 0.20 \\
\hline Total VFAs $(\mathrm{mmol} / \mathrm{L})$ & $102^{x y}$ & $105^{x}$ & $97 \mathrm{y}$ & $96^{\mathrm{y}}$ & $103^{x}$ & $101^{x y}$ & $99^{\mathrm{y}}$ & $105^{x}$ & $102^{x y}$ & 7.1 & 0.61 & 0.02 & 0.35 \\
\hline Acetic acid $\left(\mathrm{C}_{2}\right)(\mathrm{mol} / 100 \mathrm{~mol})$ & $63.1 \mathrm{cy}$ & $63.9^{b x}$ & $64.0^{\mathrm{bx}}$ & $65.4^{\text {ay }}$ & $66.5^{\text {ax }}$ & $66.3^{a x}$ & 63.9 by & $64.6^{b x}$ & $64.5^{b x}$ & 0.76 & $<0.001$ & $<0.001$ & 0.95 \\
\hline Propionic acid $\left(\mathrm{C}_{3}\right)(\mathrm{mol} / 100 \mathrm{~mol})$ & $15.5^{\mathrm{a}}$ & $15.3^{\mathrm{a}}$ & $15.3^{\mathrm{a}}$ & $15^{\mathrm{bx}}$ & $14.5^{\text {cy }}$ & $14.5^{\text {by }}$ & $15.3^{\mathrm{ax}}$ & 14.9 by & $15.2^{\mathrm{ax}}$ & 0.28 & $<0.001$ & $<0.001$ & 0.09 \\
\hline Butyric acid $(\mathrm{mol} / 100 \mathrm{~mol})$ & $13.0^{\mathrm{a}}$ & $12.6^{\mathrm{a}}$ & $12.6^{\mathrm{a}}$ & $12.1^{\mathrm{c}}$ & $12.2^{b}$ & $12^{b}$ & $12.5^{\mathrm{b}}$ & $12.8^{\mathrm{a}}$ & $12.4^{\mathrm{a}}$ & 0.45 & $<0.001$ & 0.20 & 0.16 \\
\hline Iso-butyric acid (mol/100 mol) & $1.97^{\mathrm{ax}}$ & 1.91 axy & $1.87^{\text {ay }}$ & $1.82^{b x}$ & $1.68^{\text {by }}$ & 1.72 by & $1.97^{\text {ax }}$ & $1.83^{\text {ay }}$ & $1.84^{\text {ay }}$ & 0.100 & $<0.001$ & $<0.001$ & 0.63 \\
\hline Valeric acid $(\mathrm{mol} / 100 \mathrm{~mol})$ & 2.14 axy & 2.09 ay & 2.22 ax & $1.87^{b x}$ & $1.7^{\mathrm{cy}}$ & $1.83^{\mathrm{cx}}$ & 2.12 ay & $1.95 \mathrm{bx}$ & 2.04 by & 0.107 & $<0.001$ & $<0.001$ & 0.11 \\
\hline Iso-valeric acid (mol/100 mol) & $4.27^{a x}$ & 4.09 axy & 4.04 ay & $3.87^{b x}$ & 3.5 by & 3.65 by & $4.19^{\mathrm{ax}}$ & 3.91 ay & 3.93 ay & 0.223 & $<0.001$ & $<0.001$ & 0.69 \\
\hline $\mathrm{C}_{2}: \mathrm{C}_{3}(\mathrm{~mol} / \mathrm{mol})$ & $4.1^{\mathrm{cy}}$ & $4.18^{\mathrm{cxy}}$ & $4.2^{\mathrm{bx}}$ & 4.39 ay & 4.62 ax & 4.59 ax & 4.18 by & $4.36^{b x}$ & 4.25 by & 0.109 & $<0.001$ & $<0.001$ & 0.13 \\
\hline $\mathrm{CH}_{4}: \mathrm{VFA}(\mathrm{mL} / \mathrm{mol})$ & 2.41 & $2.24^{b}$ & 2.35 & 2.53 & $2.22^{b}$ & 2.48 & 2.62 & $2.73^{\mathrm{a}}$ & 2.4 & 0.313 & 0.01 & 0.26 & 0.10 \\
\hline
\end{tabular}

${ }^{1}$ VEG: vegetative; Start-F: start of flowering; End-F: end of flowering; ${ }^{2}$ residual standard deviation; ${ }^{3}$ degraded organic matter. Within a parameter, means with
differ at $p<0.05$ for the substrate effect in each stage of maturity; with different superscripts $(\mathrm{x}, \mathrm{y}, \mathrm{z})$ at $p<0.05$ for the stage of maturity effect in each substrate. 


\section{Discussion}

In Mediterranean areas, there is an increasing interest to reintroduce forage-based systems in ovine production to ensure the viability and sustainability of the farms. Legumes are especially advisable due to their nutritional quality for ruminants and environmental benefits [1]. Moreover, the presence of $\mathrm{CT}$ in some legumes may decrease $\mathrm{CH}_{4}$ production and improve the performance of ovine to different extents depending on the source and dose of CT. As these legumes are usually fed conserved, either as silage or as hay, there is scarce information on the fermentation parameters when alfalfa and sainfoin are offered fresh. Previous experiments showed differences between the fermentation parameters of alfalfa and sainfoin hay and silage [4,30], however, it is not clear if the differences were due to the chemical composition, the presence of CT in sainfoin or both. With the present study, the fermentation parameters of alfalfa and sainfoin, with or without PEG, in fresh at different stages of maturity were compared to try to clarify the origin of the differences in fermentation. The use of gas production technique is a good tool to evaluate the effect of $\mathrm{CT}$ on fermentation parameters, but the fermentation is influenced by the time of incubation, species of the animal donor and the diet [31,32]. Furthermore, the effects of sainfoin CT vary according the variety, harvest time, and cultivation site [13,14], making it difficult to compare the results with other studies. In the present study, the content of total CT and their fractions were analyzed, however, the chemical characteristics of CT (molecular weight, degree of polymerization, prodelphinidin/procyanidin ratio, cis/trans ratio, etc.) were not evaluated.

\subsection{Effect of the Substrate}

References showed noticeable variability in the chemical composition of alfalfa and sainfoin among studies, which is related to the stage at harvest, leaf:stem ratio, soil characteristics, weather conditions, and the cultivars utilized $[5,13,14]$. In the present study, the similar CP and ADF contents and different NDF contents of alfalfa and sainfoin agree partially with the results reported by Chung et al. [10], who observed similar NDF, ADF and CP contents in fresh alfalfa and sainfoin at the late vegetative stage. However, at the early vegetative stage, the same authors observed greater NDF and ADF contents in alfalfa than sainfoin and similar CP contents.

Alfalfa has a low content of total polyphenols and is considered a CT-free legume [5], although it may present very low CT content in the seed coats. Therefore, the present results related to the presence of CTs agree with previous studies that analyzed both legumes offered fresh [33,34] or as preserved forages $[4,30]$.

The $\mathrm{pH}$ did not negatively affect the fermentation environment because the values were within the range of 6.2 to 6.8 and these values ensure a favorable environment for the activity of cellulolytic bacteria [35]. The inclusion of PEG in the current experiment did not affect $\mathrm{pH}$, as reported in fresh sainfoin [12] and sainfoin hay [8]. Regarding gas production, the similar production of alfalfa and sainfoin agrees with the similar gas production observed in alfalfa and sainfoin leaves incubated in Rusitec units [9] and alfalfa and sainfoin silages [30]. However, when alfalfa and sainfoin hays were studied, differences in gas production were reported $[3,4,8]$. The inconsistency of the results of the type of substrate on gas production might be related to the differences in chemical composition, the different characteristics of CTs and of type and settings of the in vitro assay [14]. In that sense, the similar gas production between sainfoin and sainfoin + PEG was unexpected because previous experiments reported increases in gas production when PEG was added to fresh sainfoin [12,14]. According to Azuhnwi et al. [13], the inclusion of PEG increased gas production by 2.7 to $9.6 \%$, depending on the sainfoin variety, site, and stage at harvest. In the current experiment, the inclusion of PEG slightly increased the gas production, although not statistically significantly.

The similar $\mathrm{CH}_{4}$ production of alfalfa and sainfoin recorded in the present study agrees with results reported using fresh forages [10] and silages [30]. However, the inclusion of extracts from sainfoin accessions in alfalfa decreased $\mathrm{CH}_{4}$ production, but the effect was greatly dependent on the accession and the dose of inclusion [11]. Moderate CT content may have beneficial effects reducing rumen $\mathrm{CH}_{4}$ emission production [36]. The action of $\mathrm{CT}$ on methanogenesis can be attributed to indirect 
effects via reduced hydrogen production (and presumably reduced forage digestibility) and via direct inhibitory effects on methanogens [34]. Regarding the effect of PEG, the inclusion of PEG in sainfoin did not affect $\mathrm{CH}_{4}$ production in previous studies [12,37] as in the current experiment. The structural features of condensed tannins affect in vitro $\mathrm{CH}_{4}$ production, which may be linked to the interaction of CTs with dietary substrate or microbial cells $[11,38]$. Therefore, the type of CT and dose present in the current experiment might not be sufficient to modify $\mathrm{CH}_{4}$ production.

The reduced $A$ in alfalfa compared with sainfoin and sainfoin+PEG in the start- and end-flowering stages can be related to the higher fiber fraction, as reported by Guglielmelli et al. [3]. In the current experiment, the presence of CTs in sainfoin had no effect on $A$, as reported by Calabrò et al. [8]. The higher $c$ in alfalfa when compared to sainfoin agrees with the results reported by Hatew et al. [11], although the effect on $c$ depends on the types and concentrations of sainfoin CTs.

The lower IVOMD of alfalfa, when compared to sainfoin and sainfoin+PEG, was also reported using fresh forage estimated in situ [10] and in vitro [39] and could be related to the greater fiber fraction. The increased IVOMD in sainfoin+PEG with respect to sainfoin at the vegetative stage could be related to the blockage of CTs by the PEG. However, Theodoridou et al. [12] reported no effect of the inclusion of PEG in sainfoin on IVOMD studied at $24 \mathrm{~h}$, regardless of the stage of maturity. The discrepancy between studies could be related to the content, characteristics and structures of CTs, which depends on the botanical species and variety of the source $[13,14]$.

The $\mathrm{NH}_{3}-\mathrm{N}$ contents recorded in the present study are in line with most similar studies that compared alfalfa and sainfoin $[3,4,12]$. The reduced $\mathrm{NH}_{3}-\mathrm{N}$ concentration in sainfoin with respect to alfalfa and sainfoin+PEG confirmed the inhibition elicited by CTs in the ruminal degradation of dietary proteins due to the formation of complexes CT-protein at ruminal pH [40]. In contrast, the effect of CTs on total VFA production is not clear. Some studies reported a lower total VFA production in sainfoin silage than in alfalfa silage [30], and the inclusion of different doses of extracted accession of sainfoin in alfalfa decreased or maintained the total VFA production, depending on the accession [11]. In the current experiment, the total VFA production was not affected by the legume species, as observed by other authors $[4,10]$. The inclusion of PEG did not affect total VFA production in the current experiment as reported for sainfoin hay [8,37], which is contrary to the increase of total VFA production observed by Hatew et al. [14]. The differences between the studies could be due to the time of incubation, species of the animal donor, chemical structure, and biological activity of CTs [14,31].

Generally, the presence of $\mathrm{CT}$ from sainfoin leads to an increase in the propionic acid proportion and a reduction in the $C_{2}: C_{3}$ ratio $[10,11,38]$. However, the effect on each individual VFA proportion is variable due to the type of substrate, types, and contents of CTs and length of incubation period or the donor animal $[11,31]$. In the present study, sainfoin had a greater acetic acid proportion than alfalfa, which was similar to results from Guglielmelli et al. [3] using hays and Grosse-Brinkhaus et al. [30] using silages. The $C_{2}: C_{3}$ ratio recorded in the present study was greater in sainfoin than in alfalfa and sainfoin+PEG, which is in contrast with other studies that did not observe effects of the type of substrate or the addition of PEG $[3,12,37]$. Sainfoin had lower valeric acid and branched-chain VFA proportions than alfalfa and sainfoin+PEG because of the presence of CTs [4,30,38]. Condensed tannins reduce the proportions of branched-chain VFAs due to reduce protein degradation in the rumen because these VFA are products of the breakdown of the carbon skeleton of amino acids during rumen fermentation [41].

\subsection{Effect of the Stage of Maturity}

The decrease in CP content and the concomitant increase in the cell wall (NDFom and ADFom) content as the stage of maturity progressed in both forages is a result of the decrease of the proportion of leaves to stems and the increase of lignified tissues [10]. The steady lignin (sa) content in sainfoin during the development of plants can be due to some interference between this compound and CTs during analysis, as reported by Guglielmelli et al. [3]. 
In the current experiment, the TP and TCT contents were affected by the stage of maturity, as reported in previous studies [3,5,42], although the magnitude of the effect varied among the studies. Regarding the CT fractions, there is little information about the influence of the stage of maturity. As in the present study, Chung et al. [10] observed a reduction of the ECT fraction in the end-flowering stage with respect to the vegetative stage in sainfoin. However, Jin et al. [43] observed greater TCT, ECT, and PBCT contents in Dalea purpurea at flowering than at the vegetative stage due to the high percentage of flowers, which are very rich in CTs [44]. From a physiological point of view, the reduction in the secondary compound concentrations as maturity advances could be due to a sort of dilution as a consequence of the growth and expansion of plant cells [45] and to the decrease in the leaf: stem ratio as a consequence of the reduction of leaves, which are rich in CTs [44].

The lack of an effect of the stage of maturity on $\mathrm{pH}$ values in alfalfa agrees with the results reported by Chung et al. [10], but the reduction of $\mathrm{pH}$ in sainfoin at both flowering stages disagrees with the abovementioned study. In this sense, the stage of maturity had no effect on $\mathrm{pH}$ when sainfoin hay was incubated [3,8]. More studies considering the stage of maturity, the chemical composition and the presence of secondary compounds in alfalfa and sainfoin must be performed to discern the importance of these factors on the ruminal $\mathrm{pH}$.

Previous studies reported a reduction of in vitro gas and $\mathrm{CH}_{4}$ production as the stage of maturity advanced, associated with the chemical composition and the CT content [12,46]. However, the stage of maturity had no effect on gas and $\mathrm{CH}_{4}$ production in the current experiment, which is in agreement with in vitro [3] and in vivo [10] experiments. The similar chemical composition observed between stages of maturity, the low biological activity of $\mathrm{CT}$ and the interactions between nutritive components and antinutritional factors could be responsible for the similar gas and $\mathrm{CH}_{4}$ production [3].

As expected, the IVOMD of alfalfa decreased as the fiber fraction increased with maturity [47]. In contrast, sainfoin, with or without PEG, presented considerably high IVOMD at the start-flowering stage with respect to the rest of the stages in agreement with Theodoridou et al. [12]. These results could be due to the different biological activity of CTs at vegetative and start-flowering stages [5], because the chemical composition and CT contents were similar in both stages.

The advancing of the stage of maturity tended to reduce $\mathrm{NH}_{3}-\mathrm{N}$ production as a consequence of the decrease of $\mathrm{CP}$ content in concordance with several studies carried out in vitro $[3,12]$ and in vivo $[10,42]$. Studies concerning the effect of the stage of maturity on the total production of VFAs and their proportions show discrepancies. The chemical composition of the substrates, the length of the incubation period, and the inoculum donor animal are determinant factors that can influence VFA production and proportions [31]. In the current experiment, the start-flowering stage presented the highest total VFA production, in concordance with the highest IVOMD observed. However, Theodoridou et al. [12] studied the effect of the stage of maturity of fresh sainfoin with a similar CT content in a $24 \mathrm{~h}$ in vitro assay and did not find an effect on the total VFA production.

In relation to the proportion of individual VFAs, the effect of the stage of maturity on these parameters has been reported in vitro and in vivo in previous studies $[3,10]$, but the results are not consistent. In the current experiment, as maturity advances, there is an increase in acetic acid and a decrease in propionic acid proportions, thus increasing the $C_{2}: C_{3}$ ratio due probably to increase of fiber and reduction of CT content [42]. The reduction of the proportion of iso-butyric and iso-valeric acids in the start- and end-flowering stages and valeric acid at the start-flowering stage in comparison with the vegetative stage might be explained by the decrease in $\mathrm{CP}$ content, because they are products of the breakdown of the carbon skeleton of amino acids during rumen fermentation, as the maturity of the forage advanced $[10,47]$.

\section{Conclusions}

In conclusion, sainfoin might be an alternative to alfalfa due to the high IVOMD and the potential protection against ruminal protein degradation, according to the results of ammonia content, branched-chain VFAs, and valeric acid proportion from sainfoin in vitro. The effect of the stage of 
maturity was less than expected, probably due to the high quality of the forages. It is required to study the effects of the type of substrate and stage of maturity on animal performance to recommend the best stage of maturity to cut sainfoin and alfalfa.

Author Contributions: Conceptualization, M.B.; Data curation, M.B. and M.J.; Formal analysis, P.J.R.-M. and M.B.; Funding acquisition, M.J.; Investigation, P.J.R.-M. and J.R.B.; Methodology, M.B. and M.J.; Project administration, M.J.; Resources, M.B. and M.J.; Supervision, M.B. and M.J.; Visualization, P.J.R.-M.; Writing—original draft, P.J.R.-M.; Writing—review \& editing, M.B. and M.J..

Funding: This research was funded by the Ministry of Economy and Competitiveness of Spain, the European Union Regional Development Funds (INIA RTA2012-080-00, INIA RZP2017-00001) and the Research Group Funds of the Aragón Government (A14_17R). P.J. Rufino's contract is supported by a doctoral grant from the INIA-EFS, M. Blanco has a contract supported by INIA-EFS.

Acknowledgments: Appreciation is expressed to the staff of CITA de Aragón for their help in data collection. Special thanks to the lab team and to the crop team for their assistance.

Conflicts of Interest: The authors declare no conflicts of interest.

\section{References}

1. Phelan, P.; Moloney, A.; McGeough, E.; Humphreys, J.; Bertilsson, J.; O’Riordan, E.; O'Kiely, P. Forage legumes for grazing and conserving in ruminant production systems. Crit. Rev. Plant Sci. 2015, 34, 281-326. [CrossRef]

2. Delgado, I.; Muñoz, F.; Andueza, D. Evaluación comparativa de la alfalfa y la esparceta, en condiciones de secano y regadío de Aragón. Pastos Y PAC 2014, 2020, 304-310.

3. Guglielmelli, A.; Calabrò, S.; Primi, R.; Carone, F.; Cutrignelli, M.I.; Tudisco, R.; Piccolo, G.; Ronchi, B.; Danieli, P.P. In vitro fermentation patterns and methane production of sainfoin (Onobrychis viciifolia Scop.) hay with different condensed tannin contents. Grass Forage Sci. 2011, 66, 488-500. [CrossRef]

4. Toral, P.G.; Hervás, G.; Missaoui, H.; Andrés, S.; Giráldez, F.J.; Jellali, S.; Frutos, P. Effects of a tannin-rich legume (Onobrychis viciifolia) on in vitro ruminal biohydrogenation and fermentation. Span. J. Agric. Res. 2016, 14, 1-9. [CrossRef]

5. Theodoridou, K.; Aufrère, J.; Andueza, D.; Le Morvan, A.; Picard, F.; Stringano, E.; Pourrat, J.; Mueller-Harvey, I.; Baumont, R. Effect of plant development during first and second growth cycle on chemical composition, condensed tannins and nutritive value of three sainfoin (Onobrychis viciifolia) varieties and lucerne. Grass Forage Sci. 2011, 66, 402-414. [CrossRef]

6. Alvarez-Rodriguez, J.; Sanz, A.; Ripoll-Bosch, R.; Joy, M. Do alfalfa grazing and lactation length affect the digestive tract fill of light lambs? Small Rumin. Res. 2010, 94, 109-116. [CrossRef]

7. Blanco, M.; Joy, M.; Ripoll, G.; Sauerwein, H.; Casasús, I. Grazing lucerne as fattening management for young bulls: Technical and economic performance and diet authentication. Animal 2011, 5, 113-122. [CrossRef]

8. Calabrò, S.; Guglielmelli, A.; Iannaccone, F.; Danieli, P.P.; Tudisco, R.; Ruggiero, C.; Piccolo, G.; Cutrignelli, M.I.; Infascelli, F. Fermentation kinetics of sainfoin hay with and without PEG. J. Anim. Physiol. Anim. Nutr. 2012, 96, 842-849. [CrossRef]

9. McMahon, L.; Majak, W.; McAllister, T.; Hall, J.; Jones, G.; Popp, J.; Cheng, K.-J. Effect of sainfoin on in vitro digestion of fresh alfalfa and bloat in steers. Can. J. Anim. Sci. 1999, 79, 203-212. [CrossRef]

10. Chung, Y.H.; Mc Geough, E.J.; Acharya, S.; McAllister, T.A.; McGinn, S.M.; Harstad, O.M.; Beauchemin, K.A. Enteric methane emission, diet digestibility, and nitrogen excretion from beef heifers fed sainfoin or alfalfa. J. Anim. Sci. 2013, 91, 4861-4874. [CrossRef]

11. Hatew, B.; Stringano, E.; Mueller-Harvey, I.; Hendriks, W.H.; Carbonero, C.H.; Smith, L.M.J.; Pellikaan, W.F. Impact of variation in structure of condensed tannins from sainfoin (Onobrychis viciifolia) on in vitro ruminal methane production and fermentation characteristics. J. Anim. Physiol. Anim. Nutr. 2016, 100, 348-360. [CrossRef]

12. Theodoridou, K.; Aufrère, J.; Niderkorn, V.; Andueza, D.; Le Morvan, A.; Picard, F.; Baumont, R. In vitro study of the effects of condensed tannins in sainfoin on the digestive process in the rumen at two vegetation cycles. Anim. Feed Sci. Technol. 2011, 170, 147-159. [CrossRef] 
13. Azuhnwi, B.; Boller, B.; Martens, M.; Dohme-Meier, F.; Ampuero, S.; Günter, S.; Kreuzer, M.; Hess, H. Morphology, tannin concentration and forage value of 15 Swiss accessions of sainfoin (Onobrychis viciifolia Scop.) as influenced by harvest time and cultivation site. Grass Forage Sci. 2011, 66, 474-487. [CrossRef]

14. Hatew, B.; Hayot Carbonero, C.; Stringano, E.; Sales, L.F.; Smith, L.M.J.; Mueller-Harvey, I.; Hendriks, W.H.; Pellikaan, W.F. Diversity of condensed tannin structures affects rumen in vitro methane production in sainfoin (Onobrychis viciifolia) accessions. Grass Forage Sci. 2015, 70, 474-490. [CrossRef]

15. Lobón, S.; Blanco, M.; Sanz, A.; Ripoll, G.; Joy, M. Effects of feeding strategies during lactation and the inclusion of quebracho in the fattening on performance and carcass traits in light lambs. J. Sci. Food Agric. 2019, 99, 457-463. [CrossRef]

16. Borreani, G.; Peiretti, P.G.; Tabacco, E. Evolution of yield and quality of sainfoin (Onobrychis viciifolia Scop.) in the spring growth cycle. Agronomie 2003, 23, 193-201. [CrossRef]

17. Kalu, B.A.; Fick, G.W. Quantifying Morphological Development of Alfalfa for Studies of Herbage Quality. Crop Sci. 1981, 21, 267-271. [CrossRef]

18. Rufino-Moya, P.J.; Blanco, M.; Bertolín, J.R.; Joy, M. Effect of the method of preservation on the chemical composition and in vitro fermentation characteristics in two legumes rich in condensed tannins. Anim. Feed Sci. Technol. 2019, 251, 12-20. [CrossRef]

19. Menke, K.H.; Steingass, H. Estimation of the energetic feed value obtained from chemical analysis and in vitro gas production using rumen fluid. Anim. Res. Dev. 1988, 28, 7-55.

20. AOAC. Official Methods of Analysis, 17th ed.; Association of Official Analytical Chemist: Arlington, VA, USA, 2000.

21. Van Soest, P.J.; Robertson, J.B.; Lewis, B.A. Methods for dietary fiber, neutral detergent fiber, and nonstarch polysaccharides in relation to animal nutrition. J. Dairy Sci. 1991, 74, 3583-3597. [CrossRef]

22. AOCS. Approved Procedure Am 5-04, Rapid Determination of Oil/Fat Utilizing High. Temperature Solvent Extraction; AOCS Press: Urbana, IL, USA, 2005.

23. Makkar, H.P.S. Quantification of Tannins in Tree Foliage; FAO/IAEA Working Document; IAEA: Vienna, Austria, 2000.

24. Julkunen-Tiitto, R. Phenolic Constituents in the Leaves of Northern Willows: Methods for the Analysis of Certain Phenolics. J. Agric. Food Chem. 1985, 33, 213-217. [CrossRef]

25. Terrill, T.H.; Windham, W.R.; Hoveland, C.S.; Amos, H.E. Forage preservation method influences on tannin concentration, intake and digestibility of Sericea lespedeza by sheep. Agron. J. 1989, 81, 435-439. [CrossRef]

26. Grabber, J.H.; Zeller, W.E.; Mueller-Harvey, I. Acetone enhances the direct analysis of procyanidin- and prodelphinidin-based condensed tannins in lotus species by the butanol-HCl-iron assay. J. Agric. Food Chem. 2013, 61, 2669-2678. [CrossRef] [PubMed]

27. Wolfe, R.M.; Terrill, T.H.; Muir, J.P. Drying method and origin of standard affect condensed tannin (CT) concentrations in perennial herbaceous legumes using simplified butanol-HCl CT analysis. J. Sci. Food Agric. 2008, 88, 1060-1067. [CrossRef]

28. France, J.; Dijkstra, J.; Dhanoa, M.S.; Lopez, S.; Bannink, A. Estimating the extent of degradation of ruminant feeds from a description of their gas production profiles observed in vitro: Derivation of models and other mathematical considerations. Br. J. Nutr. 2000, 83, 143-150. [CrossRef] [PubMed]

29. Chaney, A.L.; Marbach, E.P. Modified reagents for determination of urea and ammonia. Clin. Chem. 1962, 8, 130-132. [PubMed]

30. Grosse-Brinkhaus, A.; Wyss, U.; Arrigo, Y.; Girard, M.; Bee, G.; Zeitz, J.O.; Kreuzer, M.; Dohme-Meier, F. In vitro ruminal fermentation characteristics and utilisable $\mathrm{CP}$ supply of sainfoin and birdsfoot trefoil silages and their mixtures with other legumes. Animal 2017, 11, 580-590. [CrossRef]

31. Frutos, P.; Hervás, G.; Giráldez, F.J.; Mantecón, A.R. An in vitro study on the ability of polyethylene glycol to inhibit the effect of quebracho tannins and tannic acid on rumen fermentation in sheep, goats, cows, and deer. Aust. J. Agric. Res. 2004, 55, 1125-1132. [CrossRef]

32. Martínez, T.F.; McAllister, T.A.; Wang, Y.; Reuter, T. Effects of tannic acid and quebracho tannins on in vitro ruminal fermentation of wheat and corn grain. J. Sci. Food Agric. 2006, 86, 1244-1256. [CrossRef]

33. Scharenberg, A.; Arrigo, Y.; Gutzwiller, A.; Soliva, C.R.; Wyss, U.; Kreuzer, M.F.D. Palatability in sheep and in vitro nutritional value of dried and ensiled sainfoin (Onobrychis viciifolia) birdsfoot trefoil (Lotus corniculatus), and chicory (Cichorium intybus). Arch. Anim. Nutr. 2007, 61, 481-496. [CrossRef] [PubMed] 
34. Tavendale, M.H.; Meagher, L.P.; Pacheco, D.; Walker, N.; Attwood, G.T.; Sivakumaran, S. Methane production from in vitro rumen incubations with Lotus pedunculatus and Medicago sativa, and effects of extractable condensed tannin fractions on methanogenesis. Anim. Feed Sci. Technol. 2005, 123-124 Pt 1, 403-419. [CrossRef]

35. Doane, P.H.; Pell, A.N.; Schofield, P. The Effect of Preservation Method on the Neutral Detergent Soluble Fraction of Forages. J. Anim. Sci. 1997, 75, 1140-1148. [CrossRef] [PubMed]

36. Bodas, R.; Prieto, N.; García-González, R.; Andrés, S.; Giráldez, F.J.; López, S. Manipulation of rumen fermentation and methane production with plant secondary metabolites. Anim. Feed Sci. Technol. 2012, 176, 78-93. [CrossRef]

37. Niderkorn, V.; Mueller-Harvey, I.; Le Morvan, A.; Aufrère, J. Synergistic effects of mixing cocksfoot and sainfoin on in vitro rumen fermentation. Role of condensed tannins. Anim. Feed Sci. Technol. 2012, 178, 48-56. [CrossRef]

38. Huyen, N.; Fryganas, C.; Uittenbogaard, G.; Mueller-Harvey, I.; Verstegen, M.; Hendriks, W.; Pellikaan, W. Structural features of condensed tannins affect in vitro ruminal methane production and fermentation characteristics. J. Agric. Sci. 2016, 154, 1474-1487. [CrossRef]

39. Lobón, S.; Molino, F.; Legua, A.; Eseverri, M.P.; Céspedes, M.A.; Joy, M. Efecto del Forraje y de La Inclusión de Concentrado En la Dieta Sobre La Producción de Gas y Metano En Ovino. 2015. Available online: http://www.uibcongres.org/imgdb/archivo_dpo19392.pdf (accessed on 1 March 2019).

40. Mueller-Harvey, I. Unravelling the conundrum of tannins in animal nutrition and health. J. Sci. Food Agric. 2006, 86, 2010-2037. [CrossRef]

41. Hassanat, F.; Benchaar, C. Assessment of the effect of condensed (acacia and quebracho) and hydrolysable (chestnut and valonea) tannins on rumen fermentation and methane production in vitro. J. Sci. Food Agric. 2013, 93, 332-339. [CrossRef]

42. Theodoridou, K.; Aufrére, J.; Andueza, D.; Le Morvan, A.; Picard, F.; Pourrat, J.; Baumont, R. Effects of condensed tannins in wrapped silage bales of sainfoin (Onobrychis viciifolia) on in vivo and in situ digestion in sheep. Animal 2012, 6, 245-253. [CrossRef] [PubMed]

43. Jin, L.; Wang, Y.; Iwaasa, A.; Xu, Z.; Schellenberg, M.; Zhang, Y.; Liu, X.; McAllister, T. Effect of condensed tannins on ruminal degradability of purple prairie clover (Dalea purpurea Vent.) harvested at two growth stages. Anim. Feed Sci. Technol. 2012, 176, 17-25. [CrossRef]

44. Piluzza, G.; Bullitta, S. The dynamics of phenolic concentration in some pasture species and implications for animal husbandry. J. Sci. Food Agric. 2010, 90, 1452-1459. [CrossRef]

45. Joseph, R.; Tanner, G.; Larkin, P. Proanthocyanidin synthesis in the forage legume Onobrychis viciifolia. A study of chalcone synthase, dihydroflavonol 4-reductase and leucoanthocyanidin 4-reductase in developing leaves. Funct. Plant Biol. 1998, 25, 271-278. [CrossRef]

46. Bal, M.A.; Ozturk, D.; Aydin, R.; Erol, A.; Ozkan, C.O.; Ata, M.; Karakas, E.; Karabay, P. Nutritive value of sainfoin (Onobrychis viciaefolia) harvested at different maturity stages. Pak. J. Biol. Sci. 2006, 9, 205-209. [CrossRef]

47. Navarro-Villa, A.; O’Brien, M.; López, S.; Boland, T.M.; O'Kiely, P. In vitro rumen methane output of red clover and perennial ryegrass assayed using the gas production technique (GPT). Anim. Feed Sci. Technol. 2011, 168, 152-164. [CrossRef]

(C) 2019 by the authors. Licensee MDPI, Basel, Switzerland. This article is an open access article distributed under the terms and conditions of the Creative Commons Attribution (CC BY) license (http://creativecommons.org/licenses/by/4.0/). 